\title{
Exposure to Cigarette Smoke Constituents in a Population of Adult Cigarette Smokers in the U.S. Who Spontaneously Switched to Cigarettes with Lower or Higher Machine Measured 'Tar' Yield"
}

\author{
by \\ Raheema S. Muhammad-Kah, Paul Mendes, Lonnie Rimmer, Qiwei Liang, Richard Serafin, Hans J. Roethig, and \\ Mohamadi Sarkar
}

Altria Client Services, Research Development and Engineering, 601 E. Jackson Street, Richmond, VA 23219, USA

\section{SUMMARY}

Changes in exposure to cigarette smoke and smoking behavior were assessed in adult smokers participating in a multi-center, cross-sectional study who spontaneously switched to $\geq 3 \mathrm{mg}$ lower or higher machine measured 'tar' yield. Of 2,542 consenting smokers only 23 down-switchers (DWNSW) and 68 up-switchers (UPSW) met study eligibility criteria. Biomarkers of exposure (BOE) to selected smoke constituents were measured. Large variability was observed in the BOEs (e.g. CV\% for nicotine equivalents (nicotine and five of its metabolites, NE) per day ranged from $59 \%$ to $78 \%$ ). On average, DWNSW smoked two more cigarettes/day $(+9 \%)$ that had $\sim 5.9 \mathrm{mg}$ lower 'tar' yield. Mean NE/day were $12.0 \pm 6.2 \mathrm{mg} /$ day compared to $13.9 \pm 8.2 \mathrm{mg} /$ day after down switching. Slightly lower levels of NE/cigarette $(-8 \%)$, total NNAL/day and per cigarette were observed $(-18 \%$ and $-23 \%$ ) in the DWNSW's. UPSW smoked two fewer cigarettes/day $(-13 \%)$ with higher 'tar' yield $(\sim 8.4 \mathrm{mg}$ higher 'tar'). NE/day was $12.5 \pm 9.7$ vs. $12.8 \pm 9.0 \mathrm{mg} /$ day. Total NNAL values per day and per cigarette were lower $(-24 \%$ and $-17 \%)$. Due to the large variability and insufficient power to detect significant differences in exposure based on post-hoc power calculations, no definitive conclusions can be drawn from this study. These results suggest that it might not be feasible to conduct a definitive assessment of changes in exposure among spontaneous switchers. [Beitr. Tabakforsch. Int. 24 (2011) 166-173]

Keywords: cigarette, exposure, spontaneous switching, tobacco smoke, biomarkers, puffing profile

\section{ZUSAMMENFASSUNG}

Erwachsene Raucher, die spontan auf eine andere Zigarettensorte mit einem maschinell ermittelten Kondensatgehalt, der sich um mindestens $3 \mathrm{mg}$ von der ursprünglich gerauchten Sorte unterschied, gewechselt hatten, wurden aus einer multizentrischen Querschnittsuntersuchung selektiert zum Vergleich ihrer Tabakrauchexposition und ihres Rauchverhaltens vor und nach dem Wechsel. Von den 2.542 Teilnehmern dieser Studie zur Tabakrauchexposition entsprachen nur 23 sogenannte 'Down-switcher(DWNSW)' bzw. 68 'Up-switcher (UPSW)' den Bedingungen für eine Teilnahme.

Bei der Bestimmung ausgewählter Expositionsmarker (biomarkers of exposition, BOE) wurde eine große Variabilität beobachtet (z.B. lag der Variationskoeffizient für Nikotinäquivalente pro Tag (NE/d, berechnet aus Nikotin und fünf seiner Metaboliten) zwischen 59\% und $78 \%$ ). Im Durchschnitt steigerten die DWNSW ihren Zigarettenkonsum um zwei Zigaretten pro Tag, wobei der maschinelle Kondensatgehalt um $\sim 5,9 \mathrm{mg}$ sank. Die mittlere aufgenommene Menge an NE/d stieg dabei von 12,0 auf $13,9 \mathrm{mg} / \mathrm{d}$. Es wurden leicht niedrigere Werte für NE/Zig (-8\%), Gesamt-NNAL pro Tag und pro Zigarette $(-18 \%$ bzw. $-23 \%)$ gemessen. Die UPSW rauchten täglich zwei Zigaretten weniger als vorher, deren maschineller Kondensatgehalt um $\sim 8.4 \mathrm{mg}$ höher lag. Die NE-Werte lagen bei 12,5 \pm 9,7 gegenüber 12,8 \pm 9,0 mg/d. Die pro Tag bzw. pro Zigarette aufgenommenen Mengen an Gesamt-NNAL waren nach dem Wechsel um 24\% bzw. $17 \%$ niedriger. 
Es können keine endgültigen Schlussfolgerungen aus dieser Studie abgeleitet werden, da die Werte eine extrem hohe Variabilität aufwiesen und es auch nicht möglich war, signifikante Unterschiede mit einer post-hoc PowerAnalyse zu erhalten. Aufgrund dieser Ergebnisse scheint es nicht möglich zu sein, eine Veränderung der Tabakrauchexposition bei einem spontanen Wechsel der Zigarettensorte sicher zu erfassen. [Beitr. Tabakforsch. Int. 24 (2011) 166-173]

\section{RESUME}

Les modifications de l'exposition à la fumée de cigarette et le comportement tabagique ont été évalués chez des fumeurs adultes, participant à une étude transversale multicentrique, qui sont passés spontanément à une teneur en goudron mesurée par machine de $>3 \mathrm{mg}$ supérieure ou inférieure. Sur les 2542 fumeurs consentants, seuls 23 des fumeurs passés à une teneur inférieur (DWNSW) et $68 \mathrm{de}$ ceux passés à une teneur supérieure (UPSW) ont rempli les critères d'éligibilité prévus par l'étude. Les biomarqueurs d'exposition (BOE) aux composants de la fumée sélectionnés ont été mesurés. Une forte variabilité a été constatée parmi les BOE (par exemple CV \% des équivalents de la nicotine (la nicotine et cinq de ses métabolites, EN) par jour variaient de $59 \%$ à $78 \%$ ). En moyenne, les DWNSW ont fumé deux cigarettes de plus par jour (+9\%) qui avait un taux de goudron de $\sim 5,9 \mathrm{mg}$ inférieur. L'EN moyen par jour était de 12,0 $\pm 6,2 \mathrm{mg}$ par jour comparé à $13,9 \pm 8,2 \mathrm{mg}$ par jour après être passé à une teneur inférieure. Des niveaux légèrement inférieurs d'EN par cigarette ( $-8 \%$ ) et de NNAL total par jour et par cigarette ont été observés $(-18 \%$ et $-23 \%)$ parmi les DWNSW. Les UPSW ont fumé deux cigarettes de moins/jour (-13\%) avec un taux de goudron supérieur ( 8,4 mg de goudron en plus). L'EN par jour était de 12,5 $\pm 9,7$ vs. $12,8 \pm 9,0 \mathrm{mg}$ par jour. Les valeurs NNAL totales par jour et par cigarette étaient inférieures ( $-24 \%$ et $-17 \%)$. Du fait de la forte variabilité et de l'insuffisance de capacité de détection des différences significatives dans l'exposition basée sur des calculs de performance postérieurs, aucune conclusion définitive ne peut être tirée de cette étude. Ces résultats suggèrent qu'une évaluation des modifications de l'exposition des personnes changeant spontanément n'est peut-être pas réalisable. [Beitr. Tabakforsch. Int. 24 (2011) 166-173]

\section{INTRODUCTION}

Ever since the availability of cigarettes with different machine measured 'tar' yields, several studies have attempted to investigate whether exposure to cigarette smoke is different for adult smokers switching between different cigarette types $(1,2)$.

Most of these studies use a forced switching study design (3-8). Such studies can supply evidence of whether and to what extent smokers change their smoking behavior when smoking different types of cigarettes. However, conclusions from forced switching studies may be limited if the participants are not given enough time to adapt to the new cigarette type. It has been reported that the way an individual smokes a cigarette varies from day to day (9). Relative to clinic based investigations, ambulatory studies of spontaneous switching to different cigarette types might be more representative of the actual smoking conditions. To the best of our knowledge, very few studies have investigated changes in biomarkers of exposure in adult smokers who spontaneously changed cigarette brands (10-12). BURNS and BENOWITZ (6) have noted that it is difficult to obtain detailed measurements in a large sample of smokers that switch brands through their own choice.

The Total Exposure Study (TES) was a multi-center, crosssectional, ambulatory study conducted in 2002-2003 that included 3,585 U.S. adult cigarette smokers who were enrolled into one of four machine measured 'tar' yield groups: T1: $\leq 2.9 \mathrm{mg}$; T2: $3.0-6.9 \mathrm{mg}$; T3: $7.0-12.9 \mathrm{mg}$; T4: $\geq 13 \mathrm{mg}$ (13). The purpose of this TES follow-up study (FS) was to compare biomarkers of exposure (BOE) to selected cigarette smoke constituents and associated smoking behavior in adult smokers who reported having spontaneously switched, over the previous 3 months, to a cigarette brand with at least $3 \mathrm{mg}$ lower or higher machine measured 'tar' yield after their participation in the TES. A minimum difference in machine measured 'tar' yield of $3 \mathrm{mg}$ was expected to result in a detectable difference in the selected biomarkers of exposure. This switch criterion was similar to the $0.2 \mathrm{mg}$ nicotine yield used in a previous spontaneous switching study of exposure (11). The biomarkers of exposure to cigarette smoke which were used in the TES $(13,14)$ were also investigated in the FS in the same subjects.

\section{METHODS}

\section{Study design}

This follow-up study employed an observational, multicenter, ambulatory design conducted over the 2004-2005 time period. A call center mailed a postcard to adult smokers who had participated in the TES and consented to being contacted a year later. Those who pre-qualified based on the telephone interview and were interested in participating in the FS were referred to an investigative site which scheduled Visit 1 of the FS. At Visit 1, a 'tar' yield change of at least $3 \mathrm{mg}$ was verified for each prequalified volunteer. Each subject's current cigarette brand was identified and the 'tar' yield was obtained directly from the cigarette pack or from the then-current Tobacco Industry Testing Laboratory (TITL) report (15). The 'tar' yield of brands not included in the TITL reports was determined from the Federal Trade Commission Report (2000, (16)) or the brand manufacturer's website. An eligible participant had to have participated in the TES. Inclusion criteria for the FS as in the TES required that they were 21 years of age or older, in stable health, smoked at least one manufactured cigarette per day of one brand exclusively without interruption for the past three months and had not used any other tobacco- or nicotinecontaining products during the three months prior to Visit 1. Pregnant or nursing women were excluded. 


\section{Study Procedures}

The study was conducted in accordance with Good Clinical Practice (GCP) and the Declaration of Helsinki (17). Written informed consent, using an informed consent form (ICF) approved by an Institutional Review Board, was obtained from each subject in a manner consistent with GCP prior to his/her participation in the study (18). Volunteers were paid for their participation. The participants were considered generally healthy based on an assessment made by the Principal Investigator (a licensed physician) who relied on physical examination and blood chemistry measurements.

At Visit 1, a 'tar' yield change of at least $3 \mathrm{mg}$ was verified for each pre-qualified volunteer. Each participant then collected in their normal life setting a $24 \mathrm{~h}$ urine sample, which was kept in a cooler with refrigerant gel pack until returned to the site at Visit 2. Each subject also collected the butts from all cigarettes smoked during this $24 \mathrm{~h}$ urine collection period and smoked at least four cigarettes (or as many cigarettes as possible if the subject smoked fewer than four cigarettes per day) using a CReSSmicro ${ }^{\mathrm{TM}}$ portable topography measurement device (Plowshare ${ }^{\circledR}$ Technologies, Baltimore, MD) to determine the puffing profile (number of puffs per cigarette, puff volume, puff duration, inter-puff interval, and puff peak flow). Visit 2 occurred within three days of Visit 1 . At Visit 2, blood samples were also collected for biomarker determination. Blood samples were collected after a minimum $6 \mathrm{~h}$ fast and at approximately the same time of day (within $3 \mathrm{~h}$ ) as the blood sampling for the TES. Blood pressure, heart rate and body weight were also measured.

All biomarkers were measured as reported previously (8, 14, 19-22) using analytical methods validated according to the U.S. Food and Drug Administration Guidance for Industry (23).

Urine collections were considered incomplete and excluded from biomarker analyses if the creatinine excretion was $<750 \mathrm{mg} / 24 \mathrm{~h}$ for males or $<500 \mathrm{mg} / 24 \mathrm{~h}$ for females (24).

\section{Data analysis}

Evaluable subjects had complete $24 \mathrm{~h}$ urine collections in both the TES and FS. Data were summarized using descriptive statistics for each switcher group. Nicotine equivalents (NE) per cigarette ( $\mathrm{mg} / \mathrm{cig}$ ) and carboxyhemoglobin per cigarette $(\mathrm{COHb}, \%$ saturation/cigarette) were calculated for each subject as was the ratio of measured NE $(\mathrm{mg} / 24 \mathrm{~h})$ and $\mathrm{COHb}$ to the number of cigarette butts returned in a $24 \mathrm{~h}$ period.

Depending on the statistical distribution of the data, either a paired $t$-test or Wilcoxon Rank-Sum Test was used to test for a difference in biomarker levels (FS vs. TES) between the switcher groups. Differences were considered statistically significant at $p<0.05$. Based on the nature of the subject recruitment from the TES to the FS, it was not possible to predict the number of switchers entering the FS study. Additional statistical modeling was planned only if an adequate sample size was obtained.

Some measurement errors were observed in the topography parameters derived from the CReSSmicro ${ }^{\mathrm{TM}}$ device, e.g. puff volumes of $>1000 \mathrm{~mL}$ or puff duration of $>30 \mathrm{~s}$, which did not appear to be biologically plausible. Therefore, some of the observations were excluded from the analyses, based on previous observations with this device on individual smokers and plausibility considerations. Cigarettes with puff counts $\leq 3$ or $\geq 30$ were also excluded from the analyses. Puff volume outliers were identified using the Inter Quartile Range $(I Q R)$ method, $I Q R$ being the difference between the first $\left(\mathrm{Q}_{1}\right)$ and third $\left(\mathrm{Q}_{3}\right)$ quartiles. An observation was considered an outlier if it was below $\mathrm{Q}_{1}-1.5(I Q R)$ or above $\mathrm{Q}_{3}+1.5(I Q R)(25)$. For any puff volume value determined to be an outlier, the entire cigarette was excluded from the statistical analyses. For subjects who smoked more than four cigarettes using the topography device, only the first cigarette of the day, the last cigarette of the day and two cigarettes randomly chosen between the first and last cigarette were used for the analyses.

\section{RESULTS}

Of the 3,585 adult smokers in the TES, 2,542 (71\%) consented to being contacted a year later. 1,635 of the 2,542 adult smokers $(46 \%)$ were successfully contacted. Of those $1,635,284(0.8 \%$ of all adult smokers $)$ pre-qualified as having switched to a cigarette brand with at least $3 \mathrm{mg}$ lower or higher machine measured 'tar' yield and were willing to participate in the FS. However, only $91(0.3 \%$ of all adult smokers) met study eligibility criteria and were included in the FS. Non-eligible subjects were excluded mainly because switching to at least $3 \mathrm{mg}$ lower or higher machine measured 'tar' category could not be confirmed based on the information on the cigarette packages they presented at the site.

Of the 91 subjects who qualified and participated in the FS, 23 were down-switchers (DWNSW) and 68 were upswitchers (UPSW). The median time interval between TES and FS participation was 25 months in the DWNSW group and 24 months in UPSW group. This limited sample size resulted in a small statistical power of $<20 \%$ for DWNSW

Table 1. Demographics. Race: in the up-switchers, one subject had a missing value (i.e. the subject did not answer the race question in the TES); BMI: body mass index.

\begin{tabular}{lcc}
\hline & $\begin{array}{c}\text { Down-switchers } \\
(\mathrm{n}=23)\end{array}$ & $\begin{array}{c}\text { Up-switchers } \\
(\mathrm{n}=68)\end{array}$ \\
\hline $\begin{array}{l}\text { Gender, } n(\%) \\
\text { Female }\end{array}$ & $14(61)$ & $43(63)$ \\
Male & $9(39)$ & $25(37)$ \\
Age, years & & \\
Mean (SD) & $44.6(12.4)$ & $48.7(10.6)$ \\
Range (min-max) & $24-72$ & $23-78$ \\
Race, $n(\%)$ & & \\
White & $20(87)$ & $10(15)$ \\
Black & $1(4)$ & $2(3)$ \\
Other & $2(9)$ & \\
BMI $\left(\mathrm{kg} / \mathrm{m}^{2}\right)$ & & $28.7(7.54)$ \\
Mean $(\mathrm{SD})$ & $28.7(8.69)$ & \\
\hline
\end{tabular}


Table 2. Cigarette consumption, biomarkers and puffing profiles. Subjects who had urine creatinine $<750 \mathrm{mg} / 24 \mathrm{~h}$ (males), $<500 \mathrm{mg} / 24 \mathrm{~h}$ (females) in either study were pre-excluded: this caused 3 subjects to be excluded from the down-switchers, and 6 subjects to be excluded from the up-switchers. Subjects must have at least one evaluable cigarette in both the TES and follow-up puffing profile datasets to be included in the statistics. All cigarettes with $\leq 3$ or $\geq 30$ puffs were pre-excluded as inevaluable. For those remaining, evaluability was based on outliers in puff volume. Outliers were detected using the IQR (inter quartile method). Statistics are based on averaging the means of each subject's cigarette, and then averaging these means to calculate a single mean per subject.

\begin{tabular}{|c|c|c|c|c|c|c|}
\hline \multirow{3}{*}{ Parameter } & \multicolumn{3}{|c|}{ Down-switchers $(n=23)$} & \multicolumn{3}{|c|}{ Up-switchers $(n=68)$} \\
\hline & TES $^{\mathrm{a}}$ & FS & Difference & TES & FS & Difference \\
\hline & $\begin{array}{l}\text { Mean } \\
\text { (range) }\end{array}$ & $\begin{array}{l}\text { Mean } \\
\text { (range) }\end{array}$ & $\begin{array}{c}\text { Absolute } \\
(\%)^{\mathrm{b}}\end{array}$ & $\begin{array}{l}\text { Mean } \\
\text { (range) }\end{array}$ & $\begin{array}{l}\text { Mean } \\
\text { (range) }\end{array}$ & $\begin{array}{l}\text { Absolute } \\
(\%)\end{array}$ \\
\hline $\begin{array}{l}\text { Number of butts returned } \\
\text { in } 24 \mathrm{~h}\end{array}$ & $\begin{array}{l}18.0 \\
(1-76)\end{array}$ & $\begin{array}{c}19.7 \\
(5-44)\end{array}$ & $\begin{array}{c}+1.7 \\
(+9 \%)\end{array}$ & $\begin{array}{l}16.0 \\
(4-55)\end{array}$ & $\begin{array}{l}14.0 \\
(4-40)\end{array}$ & $\begin{array}{l}-2.0 \\
(-13 \%)\end{array}$ \\
\hline $\begin{array}{l}\text { Urine nicotine equivalents } \\
\text { (mg/24 h) }\end{array}$ & $\begin{array}{c}12.0 \\
(0.47-25.3)\end{array}$ & $\begin{array}{c}13.9 \\
(1.08-40.7)\end{array}$ & $\begin{array}{c}+1.9 \\
(+16 \%)\end{array}$ & $\begin{array}{c}12.5 \\
(0.12-44.3)\end{array}$ & $\begin{array}{c}12.8 \\
(0.08-32.5)\end{array}$ & $\begin{array}{c}+0.3 \\
(+2 \%)\end{array}$ \\
\hline $\begin{array}{l}\text { Urine nicotine equivalents } \\
\text { (mg/cig) }\end{array}$ & $\begin{array}{c}0.83 \\
(0.25-2.33)\end{array}$ & $\begin{array}{c}0.76 \\
(0.22-1.85)\end{array}$ & $\begin{array}{l}-0.07 \\
(-8 \%)\end{array}$ & $\begin{array}{c}0.87 \\
(0.03-3.98)\end{array}$ & $\begin{array}{c}1.03 \\
(0.02-4.81)\end{array}$ & $\begin{array}{l}+0.16 \\
(+18 \%)\end{array}$ \\
\hline $\begin{array}{l}\text { Serum cotinine } \\
(\mathrm{ng} / \mathrm{mL})\end{array}$ & $\begin{array}{c}203 \\
(5-410)\end{array}$ & $\begin{array}{c}214 \\
(5-469)\end{array}$ & $\begin{array}{c}+11 \\
(+5 \%)\end{array}$ & $\begin{array}{c}174 \\
(5-436)\end{array}$ & $\begin{array}{c}208 \\
(5-569)\end{array}$ & $\begin{array}{c}+34 \\
(+20 \%)\end{array}$ \\
\hline $\begin{array}{l}\text { Serum cotinine } \\
\text { ( } \mathrm{ng} / \mathrm{mL} \text { per cig) }\end{array}$ & $\begin{array}{c}13.1 \\
(2.59-35.5)\end{array}$ & $\begin{array}{c}12.1 \\
(1.00-26.8)\end{array}$ & $\begin{array}{c}-1 \\
(-8 \%)\end{array}$ & $\begin{array}{c}12.7 \\
(0.71-66.8)\end{array}$ & $\begin{array}{c}16.9 \\
(0.50-86.3)\end{array}$ & $\begin{array}{c}+4.2 \\
(+33 \%)\end{array}$ \\
\hline $\begin{array}{l}\text { Urine total NNAL } \\
(\mathrm{ng} / 24 \mathrm{~h})\end{array}$ & $\begin{array}{c}473 \\
(6.50-1202)\end{array}$ & $\begin{array}{c}386 \\
(25.4-1114)\end{array}$ & $\begin{array}{c}-87 \\
(-18 \%)\end{array}$ & $\begin{array}{c}427 \\
(10.5-1805)\end{array}$ & $\begin{array}{c}326 \\
(2.31-1222)\end{array}$ & $\begin{array}{l}-101 \\
(-24 \%)\end{array}$ \\
\hline $\begin{array}{l}\text { Urine total NNAL } \\
\text { (ng/cig) }\end{array}$ & $\begin{array}{c}28.4 \\
(6.5-59.2)\end{array}$ & $\begin{array}{c}21.9 \\
(2.66-50.6)\end{array}$ & $\begin{array}{c}-6.5 \\
(-23 \%)\end{array}$ & $\begin{array}{c}30.2 \\
(1.03-119)\end{array}$ & $\begin{array}{c}25.1 \\
(0.58-127)\end{array}$ & $\begin{array}{c}-5.1 \\
(-17 \%)\end{array}$ \\
\hline $\begin{array}{l}\text { Urine total 1-OHP } \\
(\mathrm{ng} / 24 \mathrm{~h})\end{array}$ & $\begin{array}{c}205 \\
(52.3-443)\end{array}$ & $\begin{array}{c}282 \\
(83.9-715)\end{array}$ & $\begin{array}{c}+77 \\
(+38 \%)\end{array}$ & $\begin{array}{c}284 \\
(34.3-1097)\end{array}$ & $\begin{array}{c}351 \\
(23.7-2003)\end{array}$ & $\begin{array}{c}+67 \\
(+24 \%)\end{array}$ \\
\hline $\begin{array}{l}\text { Urine total 1-OHP } \\
\text { (ng/cig) }\end{array}$ & $\begin{array}{c}16.3 \\
(2.81-52.3)\end{array}$ & $\begin{array}{c}15.7 \\
(3.50-35.8)\end{array}$ & $\begin{array}{l}-0.6 \\
(-4 \%)\end{array}$ & $\begin{array}{c}26.2 \\
(1.80-274)\end{array}$ & $\begin{array}{c}30.8 \\
(3.32-134)\end{array}$ & $\begin{array}{l}+4.6 \\
(+18 \%)\end{array}$ \\
\hline $\begin{array}{l}\text { Urine 3-HPMA } \\
(\mu \mathrm{g} / 24 \mathrm{~h})\end{array}$ & $\begin{array}{c}1580 \\
(206-2957)\end{array}$ & $\begin{array}{c}2212 \\
(478-4444)\end{array}$ & $\begin{array}{c}+632 \\
(+40 \%)\end{array}$ & $\begin{array}{c}2054 \\
(184-10395)\end{array}$ & $\begin{array}{c}1907 \\
(239-5827)\end{array}$ & $\begin{array}{l}-147 \\
(-7 \%)\end{array}$ \\
\hline $\begin{array}{l}\text { Urine 3-HPMA } \\
(\mu \mathrm{g} / \mathrm{cig})\end{array}$ & $\begin{array}{c}115 \\
(25.9-257)\end{array}$ & $\begin{array}{c}123 \\
(46.6-251)\end{array}$ & $\begin{array}{c}+8 \\
(+7 \%)\end{array}$ & $\begin{array}{c}151 \\
(22.7-693)\end{array}$ & $\begin{array}{c}149 \\
(26.3-921)\end{array}$ & $\begin{array}{c}-2 \\
(-1 \%)\end{array}$ \\
\hline $\begin{array}{l}\text { Urine MHBMA } \\
(\mu \mathrm{g} / 24 \mathrm{~h})\end{array}$ & $\begin{array}{c}3.7 \\
(0.13-14.0)\end{array}$ & $\begin{array}{c}4.2 \\
(0.72-15.5)\end{array}$ & $\begin{array}{c}+0.5 \\
(+14 \%)\end{array}$ & $\begin{array}{c}3.6 \\
(0.03-12.7)\end{array}$ & $\begin{array}{c}4.0 \\
(0.05-12.3)\end{array}$ & $\begin{array}{c}+0.4 \\
(+11 \%)\end{array}$ \\
\hline $\begin{array}{l}\text { Urine MHBMA } \\
(\mu \mathrm{g} / \mathrm{cig})\end{array}$ & $\begin{array}{c}0.223 \\
(0.014-0.761)\end{array}$ & $\begin{array}{c}0.226 \\
(0.029-0.702)\end{array}$ & $\begin{array}{c}+0.003 \\
(+1 \%)\end{array}$ & $\begin{array}{c}0.263 \\
(0.005-1.08)\end{array}$ & $\begin{array}{c}0.305 \\
(0.007-1.39)\end{array}$ & $\begin{array}{l}+0.042 \\
(+16 \%)\end{array}$ \\
\hline $\begin{array}{r}\text { 4-ABP Hb } \\
(\mathrm{pg} / \mathrm{g} \mathrm{Hb})\end{array}$ & $\begin{array}{c}24.4 \\
(8.93-45.3)\end{array}$ & $\begin{array}{c}35.1 \\
(18.2-56.1)\end{array}$ & $\begin{array}{l}+10.7 \\
(+44 \%)\end{array}$ & $\begin{array}{c}32.1 \\
(2.79-95.4)\end{array}$ & $\begin{array}{c}65.1 \\
(6.32-683)\end{array}$ & $\begin{array}{c}+33.0 \\
(+103 \%)\end{array}$ \\
\hline $\begin{array}{l}\text { Carboxyhemoglobin }{ }^{d} \\
(\% \text { saturation })\end{array}$ & $\begin{array}{c}5.3 \\
(1.30-10.9)\end{array}$ & $\begin{array}{c}7.0 \\
(1.90-11.8)\end{array}$ & $\begin{array}{c}+1.7 \\
(+32 \%)\end{array}$ & $\begin{array}{c}5.3 \\
(1.30-15.1)\end{array}$ & $\begin{array}{c}6.1 \\
(1.60-14.6)\end{array}$ & $\begin{array}{c}+0.8 \\
(+15 \%)\end{array}$ \\
\hline $\begin{array}{l}\text { Carboxyhemoglobin } \\
\text { (\% saturation/cig) }\end{array}$ & $\begin{array}{c}0.40 \\
(0.11-1.30)\end{array}$ & $\begin{array}{c}0.39 \\
(0.10-0.92)\end{array}$ & $\begin{array}{l}-0.01 \\
(-2 \%)\end{array}$ & $\begin{array}{c}0.40 \\
(0.11-1.88)\end{array}$ & $\begin{array}{c}0.51 \\
(0.15-1.98)\end{array}$ & $\begin{array}{c}+0.11 \\
(+26 \%)\end{array}$ \\
\hline $\begin{array}{l}\text { Number of puffs per } \\
\text { cigarette }\end{array}$ & $\begin{array}{c}11.6 \\
(6.0-21.0)\end{array}$ & $\begin{array}{c}12.1 \\
(4.5-26.0)\end{array}$ & $\begin{array}{c}+0.5 \\
(+4 \%)\end{array}$ & $\begin{array}{c}11.7 \\
(4.0-20.0)\end{array}$ & $\begin{array}{c}12.6 \\
(7.3-21.0)\end{array}$ & $\begin{array}{l}+0.9 \\
(+8 \%)\end{array}$ \\
\hline $\begin{array}{l}\text { Puff volume } \\
(\mathrm{mL})\end{array}$ & $\begin{array}{c}40.5 \\
(13.9-65.1)\end{array}$ & $\begin{array}{c}45.4 \\
(16.6-78.6)\end{array}$ & $\begin{array}{c}+4.9 \\
(+12 \%)\end{array}$ & $\begin{array}{c}43.1 \\
(8.6-84.3)\end{array}$ & $\begin{array}{c}44.0 \\
(18.4-77.5)\end{array}$ & $\begin{array}{l}+0.9 \\
(+2 \%)\end{array}$ \\
\hline $\begin{array}{l}\text { Puff duration } \\
\text { (s) }\end{array}$ & $\begin{array}{c}1.08 \\
(0.47-1.77)\end{array}$ & $\begin{array}{c}1.24 \\
(0.55-2.25)\end{array}$ & $\begin{array}{c}+0.16 \\
(+15 \%)\end{array}$ & $\begin{array}{c}1.12 \\
(0.27-1.99)\end{array}$ & $\begin{array}{c}1.16 \\
(0.52-1.85)\end{array}$ & $\begin{array}{l}+0.04 \\
(+4 \%)\end{array}$ \\
\hline
\end{tabular}

a TES: only subjects that participated in the follow-up study and had evaluable data.

${ }^{\mathrm{b}}$ Absolute difference $=$ follow-up mean value - TES mean value

${ }^{c} \%$ difference $=[($ follow-up mean value - TES mean value $) /($ TES mean value $)]{ }^{*} 100$.

${ }^{d}$ For carboxyhemoglobin and 4-ABP Hb, subjects were included as ' $n$ ' in this table only if they have non-missing data in both the TES and follow-up study.

and $<10 \%$ for UPSW based on NE. There was also a large variability in all biomarkers in both groups (e.g. the coefficient of variation (CV \%) for NE per day ranged from $59 \%$ to $78 \%$ ).

Prior to switching, the DWNSW group smoked higher machine measured 'tar' yield cigarettes, on average, than the UPSW group. As observed in the TES $(13,14)$ the ranges in both groups were large for all the biomarkers of exposure.

Compared to the TES, the average machine measured 'tar' yield was $43 \%$ lower in the FS in the DWNSW, (i.e. they switched from an average of $13.9 \mathrm{mg}$ to an average of $8.0 \mathrm{mg}$ ), and $270 \%$ higher in the UPSW (i.e. they switched from an average of $3.1 \mathrm{mg}$ to an average of $11.5 \mathrm{mg}$ ). 
A. Mean $=\cdot, 25^{\text {th }}$ percentile $=$ lower edge of box, $50^{\text {th }}$ percentile $=$ line inside box, $75^{\text {th }}$ percentile $=$ upper edge of box minimum $=$ endpoint of lower whisker, maximum= endpoint of upper whisker

Urine Nicotine Equivalents $(\mathrm{mg} / 24 \mathrm{~h})$

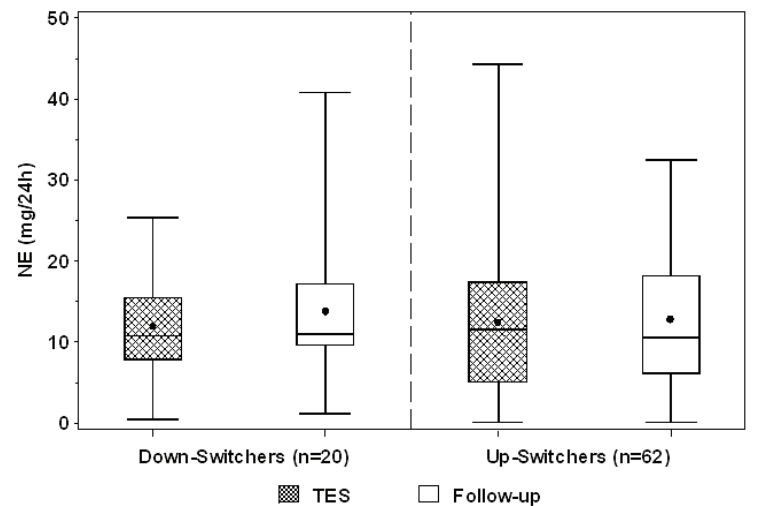

B.

\section{Carboxyhemoglobin (\% saturation)}

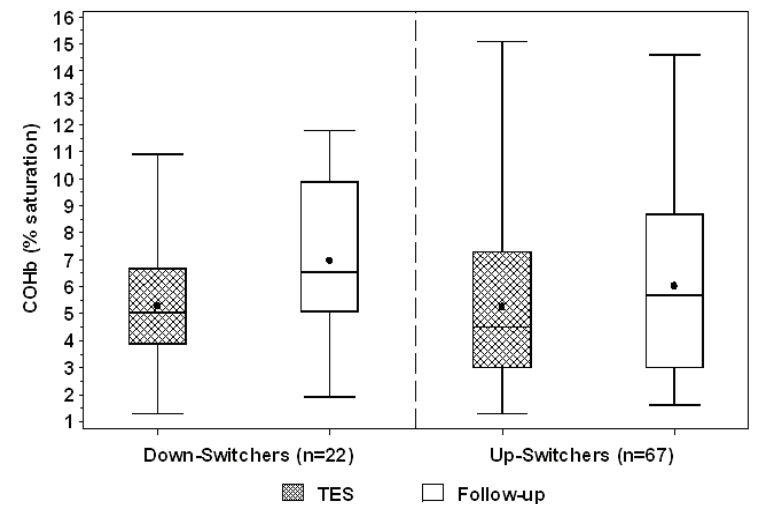

C.

Urine Total NNAL (ng/24h)

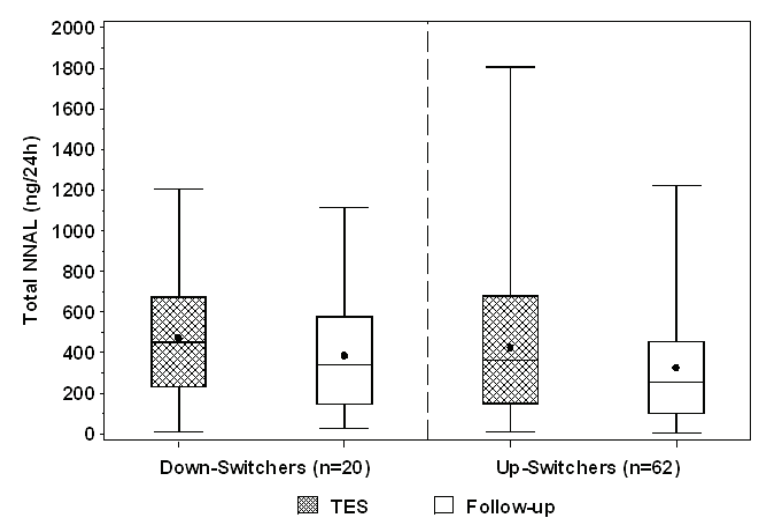

Urine Nicotine Equivalents per Cigarette (mg/cig)

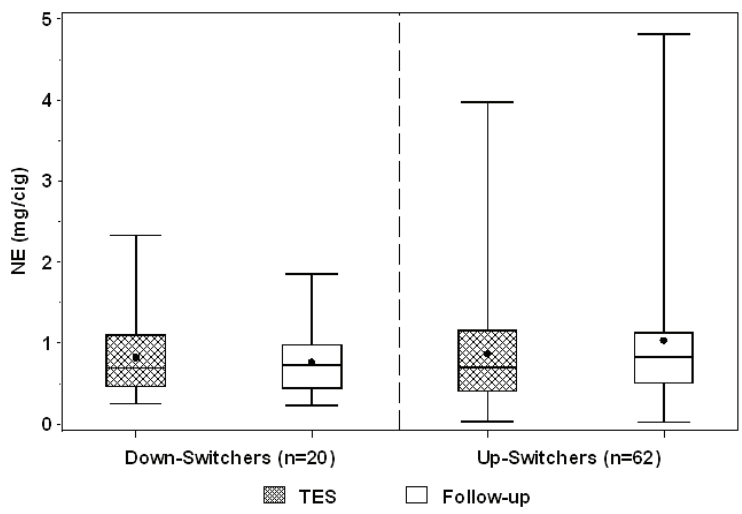

\section{Carboxyhemoglobin (\% saturation) per Cigarette}

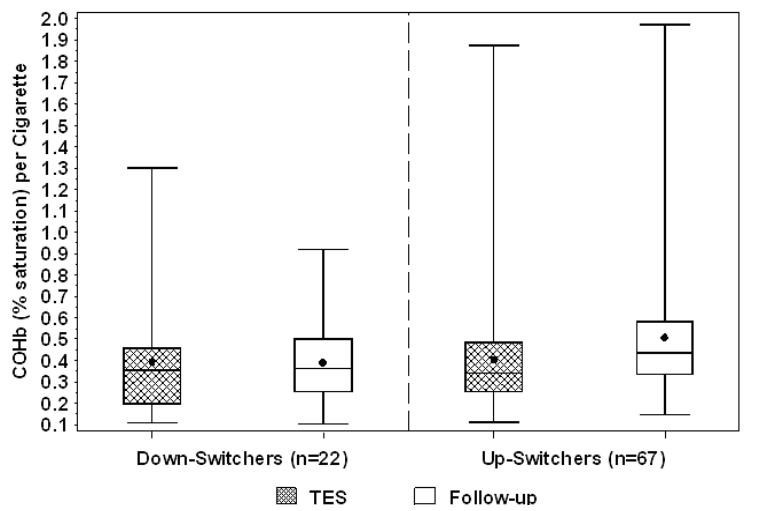

Urine Total NNAL per Cigarette (ng/cig)

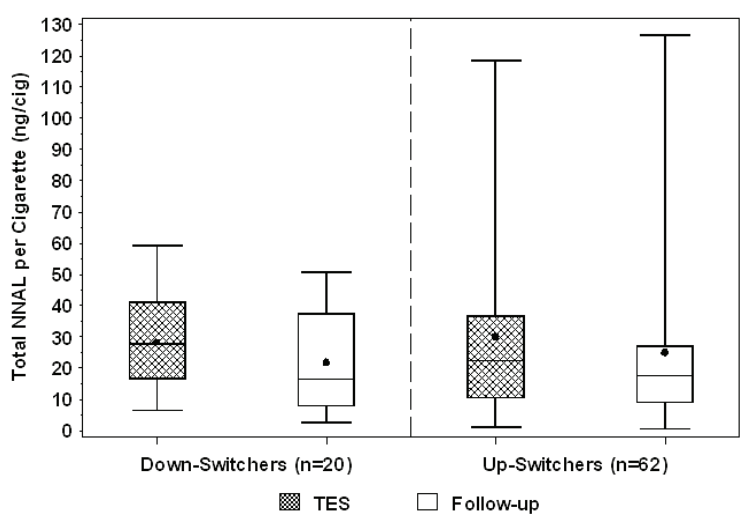

Figure 1. Changes in biomarkers of exposure. Subjects who had urine creatinine $<750 \mathrm{mg} / 24 \mathrm{~h}$ (males), $<500 \mathrm{mg} / 24 \mathrm{~h}$ (females) in EITHER study were pre-excluded: This caused 3 subjects to be excluded from the Down-switchers, and 6 subjects to be excluded from the Up-switchers. For carboxyhemoglobin, subjects were included as ' $n$ ' in this table only if they have non-missing data in both the TES and follow-up study.

Both groups generally had similar demographic characteristics. There was a larger number of switchers among Whites compared to African Americans (Table 1). Mean cigarette consumption, biomarker data and puffing profiles are presented in Table 2 for both switcher groups. Wide ranges of values for all assessed biomarkers were observed in both switcher groups in both the TES and the FS. Changes in the selected biomarkers of exposure are depicted in Figure 1.

Down-switchers: based on the 'tar' yield category groups in the TES (T1: $\leq 2.9 \mathrm{mg}$; T2: $3.0-6.9 \mathrm{mg}$; T3: $7.0-12.9 \mathrm{mg}$; T4: $\geq 13,0 \mathrm{mg}$ ), in the FS, 13 subjects in the 
DWNSW group switched from a T4 to T3 and 3 from T4 to $\mathrm{T} 2 ; 4$ subjects switched from $\mathrm{T} 3$ to $\mathrm{T} 2$ and 3 to a lower machine measured 'tar' yield within the same machine measured 'tar' yield category (i.e. T3). The biomarkers and topography data are listed in Table 2 . The mean number of smoked cigarettes per day increased by about 2 cigarettes in the FS. The mean NE per day in the FS and TES were not statistically significantly different $(p=0.1140)$. Sixtyfive percent of DWNSW had an increase in NE per day after switching to a lower machine measured 'tar' yield and $35 \%$ had a decrease in NE per day. The mean total NNAL per day was lower in the FS than in the TES, the differences only reached borderline statistical significance $(p=0.0449)$. The mean $\mathrm{COHb}$ was statistically significantly higher $(p=0.0052)$ in the FS than in the TES. Mean values of cotinine, total 1-OHP, 3-HPMA, MHBMA, and 4-ABP-Hb were generally higher in the FS, but when adjusted for the number of cigarettes smoked per day, they were generally comparable to the TES. In the FS, the DWNSW group had on average, 0.5 more puffs per cigarette, $12 \%$ larger mean puff volume and 15\% longer mean puff duration as compared to the TES.

Up-switchers: among the UPSW, 37 switched from T1 to higher machine measured 'tar' yield categories, 15 to T4, 13 to $\mathrm{T} 3$ and 9 to $\mathrm{T} 2$. Of 28 subjects smoking cigarettes from the T2 machine measured 'tar' yield category in the TES, 6 switched from T2 to T4, and 22 from T2 to T3. Only 2 switched from T3 to T4 and 1 from T4 to a higher machine measured 'tar' yield in the same category. The biomarkers and topography data are listed in Table 2. Mean number of smoked cigarettes per day decreased by 2 cigarettes in the FS. The mean NE per day values were not statistically significantly different between the TES and FS groups $(p=0.2405)$. Fifty-seven percent of UPSW had an increase in NE per day after switching to a higher machine measured 'tar' yield and $43 \%$ had a decrease in NE per day. There were no statistically significant differences between the FS and TES for the mean total NNAL per day $(p=0.0510)$. Mean $\mathrm{COHb}$ was statistically significantly higher $(p=0.0001)$ in the FS than in the TES. Mean values of cotinine, total 1-OHP, 4-ABP-Hb, and MHBMA were generally higher in the FS compared to TES when the values were adjusted for the number of cigarettes smoked per day. The mean value of 3-HPMA was slightly lower in the FS. The average topography values in the UPSW group in the FS were comparable to the TES.

\section{DISCUSSION}

We investigated the exposure to cigarette smoke, cigarette consumption and puffing profiles when adult smokers spontaneously switched in their normal life setting to a cigarette brand with at least a $3 \mathrm{mg}$ different machine measured 'tar' yield. A minimum difference in machine measured 'tar' yield of $3 \mathrm{mg}$ was expected to result in a detectable difference in the selected biomarkers of exposure. This switch criterion was similar to the $0.2 \mathrm{mg}$ nicotine yield used in a previous spontaneous switching study of exposure (11).

The large variability and the relatively small sample size limits the conclusions that can be drawn from this analysis.
The univariate statistical comparisons should be interpreted with caution. Due to the limited sample size and the inherent variability typically observed in biomarkers of exposure to non-tobacco specific constituents (14), the biomarkers of exposure to tobacco specific constituents were used to gain potential insight between the two switcher groups.

The sample size of this follow-up study was dependent on the number of smokers from the TES who spontaneously switched brands ( $\geq 3 \mathrm{mg}$ ) and met all other eligibility criteria. Despite contacting 1,635 consenting TES adult smokers, only 91 were ultimately eligible and evaluable. The majority of subjects failed eligibility because a change of at least $3 \mathrm{mg}$ higher or lower machine measured 'tar' yield could not be verified at Visit 2. The sample of adult smokers in this study cannot be considered representative of the U.S. adult smoker population and thus these data are not generalizable. A post-hoc power calculation revealed that the power of the study was insufficient to detect statistically significant differences between the mean biomarker levels in the TES and the FS. A post-hoc power analysis for a paired $t$-test showed that in order to get a $80 \%$ power of detecting a statistical significant difference in NE $(\mathrm{mg} / 24 \mathrm{~h})$ between the TES and the FS with a 5\% type I error, 169 DWNSW and 3,164 UPSW would have been required.

The only previous study with comparable study design had 62 down-switchers and 31 up-switchers despite selecting subjects from adult smokers who had participated in two previous large studies over a 3 to 6-year period (11). The observations in the FS regarding changes in number of cigarettes and nicotine excretion are directionally similar to the previous report (14). DWNSW generally smoked slightly more cigarettes whereas the UPSW smoked slightly fewer cigarettes. The differences in number of cigarettes did not appear to manifest into statistically significant differences in NE excretion, although the lack of statistical significance could also be due to the large variability and small sample size. Due to the relatively small changes in puffing parameters, it is difficult to draw definitive conclusions regarding any possible changes in smoking behavior as it relates to smoking topography. The reason for the relatively large changes in the levels of the acrolein metabolite, 3-HPMA, are unclear, particularly considering that the primary biomarker of exposure to cigarette smoke, NE, was similar between the two groups.

It was also observed that unlike the lack of differences between the two groups for NE, total NNAL levels were lower in both DWNSW and UPSW. The decrease in total NNAL per day and total NNAL per cigarette in both groups could possibly be due to the efforts by the U.S. tobacco industry to reduce tobacco-specific nitrosamines in tobacco due to changes in the tobacco curing process since 2000 $(26,27)$. Since tobacco is an agricultural product, fluctuations in machine measured yields of smoke constituents are also possible. The 'tar' yield estimates were obtained from annual reports by the industry. It is possible that the 'tar' yields might not accurately reflect the exact 'tar' yield of the cigarettes smoked by the participants during the study. However, in order to avoid impact on consumer acceptability, cigarette manufacturers make every attempt to avoid fluctuations beyond $\pm 1 \mathrm{mg}$ or $15 \%$ at the lower 'tar' 
yields. Therefore it is unlikely that the 'tar' yields would fluctuate to a large extent. This consistency in machine measured 'tar' yields of cigarettes would suggest that the utilization of the annual reports would be a reasonable estimate of the 'tar' yields of the cigarettes smoked by the participants.

The results of this study and the fact that only one comparable study has been published raise the question of whether a definitive assessment of exposure in spontaneous switchers is at all feasible. Switching to cigarettes with different machine measured 'tar' yields may be better investigated in a randomized, controlled, force-switching study (7).

\section{ACKNOWLEDGMENT}

Financial support supplied by Philip Morris USA Inc.

\section{REFERENCES}

1. Wald, N.J., J. Boreham, and A. Bailey: Relative intakes of tar, nicotine, and carbon monoxide from cigarettes of different yields; Thorax 39 (1984) 361-364.

2. Russell, M.A., M.J. Jarvis, C. Feyerabend, and Y. Saloojee: Reduction of tar, nicotine and carbon monoxide intake in low tar smokers; J. Epidemiol. Community Health 40 (1986) 80-85.

3. Benowitz, N.L., S.M. Hall, R.I. Herning, P. Jacob, R.T. Jones, and A.L. Osman : Smokers of low-yield cigarettes do not consume less nicotine; N. Engl. J. Med. 309 (1983) 139-142.

4. Benowitz, N.L., P. Jacob, J.T. Bernert, M. Wilson, L.Wang., F. Allen, D. Dempsey: Carcinogen exposure during short-term switching from regular to "light" cigarettes; Cancer Epidemiol. Biomarkers Prev. 14 (2005) 1376-1383.

5. Benowitz, N.L.: Compensatory smoking of low yield cigarettes. In: Risk associated with smoking cigarettes with low machine-measured yields of tar and nicotine, edited by D.R. Shopland, D.M. Burns, N.L. Benowitz, and R.H. Amacher. NCI Smoking and Tobacco Control Monograph No. 13. Bethesda, (MD): U.S. NIH, National Cancer Institute, NIH Publication. No. 025074 (2001) pp. 39-64.

6. Burns, D.M. and N.L. Benowitz.: Public health implications of changes in cigarette design and marketing. In: Risk associated with smoking cigarettes with low machine-measured yields of tar and nicotine,edited by D.R. Shopland, D.M. Burns, N.L. Benowitz and R.H. Amacher; NCI Smoking and Tobacco Control Monograph No. 13. Bethesda (MD): U.S. NIH, National Cancer Institute, NIH Publication No. 02-5074 (2001) pp. 1-12.

7. Mendes, P., S. Kapur, J. Wang, S. Feng, and H.J. Roethig: A randomized, controlled exposure study in adult smokers of full flavor Marlboro cigarettes switching to Marlboro Lights or Marlboro Ultra Lights cigarettes; Regul. Toxicol. Pharmacol. 51 (2008) 295-305.
8. Roethig, H.J., R.D. Kinser, R.W. Lau, R.A. Walk, and N. Wang: Short-term exposure evaluation of adult smokers switching from conventional to first-generation electrically-heated cigarettes during controlled smoking; J. Clin. Pharmacol. 45 (2005) 133-45.

9. Scherer, G.: Smoking behavior and compensation: a review of the literature; Psychopharmacology 145 (1999) 1-20.

10. Heller, W.D., G. Scherer, J.G. Gostomzyk, J. Stieber, and F. Adlkofer: Cotinine concentration in the serum of smokers within a representative population in Southern Germany measured in 1984/85 and 87/88. Poster presented at the Symposium "Effects of nicotine on biological systems", Hamburg, Germany, June 28-30, 1990.

11. Lynch, C. J. and N.L.Benowitz: Spontaneous cigarette brand switching: Consequences for nicotine and carbon monoxide exposure; Am. J. Public Health 78 (1987) 1191-1194.

12. Peach, H., D.M..Hayward, D.R. Ellard, R.W. Morris, and D. Shah: Phlegm production and lung function among cigarette smokers changing tar groups during the 1970s; J. Epidemiol. Community Health 40 (1986) 110-116.

13. Mendes, P.E., Q.Liang, K. Frost-Pineda, S. Munjal, H.J. Roethig, and R.A.Walk: The relationship between smoking machine derived tar yields and biomarkers of exposure in adult cigarette smokers in the U.S.; Regul. Toxicol. Pharmacol. 55 (2009) 17-27.

14. Roethig, H.J., S. Munjal, S. Feng, Q. Liang, M. Sarkar, R.A.Walk, and P.E. Mendes : Population estimates for biomarkers of exposure to selected cigarette smoke constituents of adult U.S. cigarette smokers; Nicotine Tob. Res. 10 (2009) 1216-25.

15. Tobacco Institute Testing Laboratory. Testing Laboratory Market Sample \# 45 Final Report, "Tar ", "Nicotine ", and Carbon Monoxide Values. Tobacco Institute Testing Laboratory, Rockville, MD, USA 2003.

16. United States Federal Trade Commission. "Tar," Nicotine and Carbon Monoxide of the Smoke of 1294 Varieties of Domestic Cigarettes for the Year 1998. U.S. Federal Trade Commission. Available from: http://www.ftc.gov/reports/tobacco/1998tar\&nicotine report.pdf (Accessed on March 20, 2008).

17. International Conference on Harmonisation of Technical Requirements for Registration of Pharmaceuticals for Clinical Use. ICH Tripartite guideline for good clinical practice. International Conference on Harmonisation. Available at http://www.ich.org/LOB/media/ MEDIA482.pdf (Accessed on March 20, 2008).

18. World Medical Association. Declaration of Helsinki: Ethical Principles for Medical Research Involving Human Subjects. 52nd World Medical Association General Assembly, Edinburgh, Scotland. Available at http://www.wma.net/e/policy/pdf/17c.pdf(Accessed on March 20, 2008).

19. Roethig, H.J., B.K. Zedler, R.D. Kinser, S. Feng, B. Nelson, and Q. Liang: Short-term clinical exposure evaluation of a second-generation electrically heated cigarettes smoking system; J. Clin. Pharmacol. 47 (2007) 518-30.

20. Sarkar, M., R. Stabbert, R.D. Kinser, J. Oey, K. Ruste- 
meier, K. von Holt, G. Schepers, R.A. Walk, and H.J. Roethig: CYP1A2 and NAT2 phenotyping and 3aminobiphenyl and 4-aminobiphenyl hemoglobin adduct levels in smokers and non-smokers; Toxicol. Appl. Pharmacol. 213 (2006) 198-206.

21. Urban, M., G. Gilch, G. Schepers, E. van Miert, and G. Scherer: Determination of the major mercapturic acids of 1,3-butadiene in human and rat urine using liquid chromatography with tandem mass spectrometry; J. Chromatogr. B 796 (2003) 131-140.

22. Zedler, B.K., R. Kinser, J. Oey, B. Nelson, H.J. Roethig, R.A. Walk, P. Kuhl, K. Rustemeier, G. Schepers, K. Von Holt, and R.A.Tricker : Biomarkers of exposure and potential harm in adult smokers of 3-7 mg tar yield (Federal Trade Commission) cigarettes and in adult non-smokers; Biomarkers 11 (2006) 201-220.

23. Guidance for Industry. Bioanalytical Method Validation. U.S. Department of Health and Human Services and U.S. Food and Drug Administration, 2001. Available from http://www.fda.gov/cder/ guidance/4252fnl.pdf (Accessed on March 20, 2008).

24. Burtis, C.A. and E.R. Ashwood (Eds.): Tietz Textbook of Clinical Chemistry. W. B. Saunders Company,
Philadelphia, 1999.

25. Tukey, J.W.: Exploratory data analysis. Reading, MA: Addison-Wesley, 1977, pp 688.

26. Fisher, B: Curing the TNSA problem. Tob. Rep. 127 (2000) 51-58

27. Nestor, T. B., J.S. Gentry, D.M. Peele, M.G. Riddick, B.T. Conner, and M.E. Edwards: Role of Oxides of Nitrogen in Tobacco-specific Nitrosamine Formation in Flue-cured Tobacco; Beitr. Tabakforsch. Int. 20 (2003) 467-475.

Corresponding author:

Raheema S. Muhammad-Kah

Altria Client Services

Research Development and Engineering

601 E. Jackson Street

Richmond, VA 23219

USA

E-mail: SciencePublications@altria.com 